\title{
Fish-bone peptide increases calcium solubility and bioavailability in ovariectomised rats
}

\author{
Won-Kyo Jung ${ }^{1,2}$, Bae-Jin Lee ${ }^{1,3}$ and Se-Kwon Kim ${ }^{1,2 *}$ \\ ${ }^{1}$ Department of Chemistry, Pukyong National University, Busan 608-737, Republic of Korea \\ ${ }^{2}$ Marine Bioprocess Research Center, Pukyong National University, Busan 608-737, Republic of Korea \\ ${ }^{3}$ Marine Bioprocess Co., Ltd., Pukyong National University, Busan 608-737, Republic of Korea
}

(Received 27 January 2005 - Revised 2 September 2005 - Accepted 2 September 2005)

\begin{abstract}
Fish-bone peptides (FBP) with a high affinity to Ca were isolated using hydroxyapatite affinity chromatography, and FBP II with a high ratio of phosphopeptide was fractionated in the range of molecular weight $5 \cdot 0-1 \cdot 0 \mathrm{kDa}$ by ultramembrane filtration. In vitro study elucidated that FBP II could inhibit the formation of insoluble Ca salts in neutral $\mathrm{pH}$. In vivo effects of FBP II on Ca bioavailability were further examined in the ovariectomised rat. During the experimental period, Ca retention was increased and loss of bone mineral was decreased by FBP II supplementation in ovariectomised rats. After the low-Ca diet, the FBP II diet, including both normal level of Ca and vitamin D, significantly decreased Ca loss in faeces and increased $\mathrm{Ca}$ retention compared with the control diet. The levels of femoral total $\mathrm{Ca}$, bone mineral density, and strength were also significantly increased by the FBP II diet to levels similar to those of the casein phosphopeptide diet group (no difference; $P>0$.05). In the present study, the results proved the beneficial effects of fish-meal in preventing Ca deficiency due to increased Ca bioavailability by FBP intake.
\end{abstract}

Fish-bone peptides: Calcium solubility: Ovariectomised rats: Calcium bioavailability

The major source of $\mathrm{Ca}$ is the diet, and the most common and trusted source of $\mathrm{Ca}$ is milk or other dairy products (Anderson \& Garner, 1996). Dairy products contain a high content of casein. Casein phosphopeptides (CPP) derived from the intestinal digestion of casein have been shown to enhance bone calcification in rats (Lee et al. 1980; Tsuchita et al. 1993). Such CPP have the capacity to chelate $\mathrm{Ca}$ and to prevent the precipitation of Ca phosphate salts (Berrocal et al. 1989), thereby increasing the amount of soluble Ca availability for absorption across the mucosa (Yuan \& Kitts, 1991, 1994).

However, some oriental people do not drink milk due to lactose indigestion and intolerance, which make them allergic to milk. Thus, there have been many studies on various Ca supplements as alternatives (for examples, soya protein isolate, fructo-oligosaccharide, fish-meal, etc), which may affect $\mathrm{Ca}$ bioavailability (Brouns \& Vermeer, 2000; Larsen et al. 2000, 2003; Kumagai et al. 2004). As reported by Larsen et al. (2000), the intake of small fish with bones could increase Ca bioavailability in rats, and small fish might be an important $\mathrm{Ca}$ dietary supplement, especially in population groups with low intakes of milk and dairy products.

Annually, more than $50 \%$ of total fishery products (over 120 million tons) are discarded as inedible by-products, such as bone, skin, fins, internal organs and head. Thus, many studies have been performed to utilise the large amounts of protein, oil, minerals, carbohydrate and nucleic acid originating from fishery by-products, and to improve their functional properties (Nair \& Gopakumar, 1982; Rodriguez-Estrada et al. 1994; Nagai \& Suzuki, 2000; Kim et al. 2001, 2003; Shahidi \& Janak Kamil, 2001). However, studies on the utilisation of organic components or minerals in fish bone are scarce (Kim et al. 1997; Larsen et al. 2000, 2003). In our previous study (Jung et al. 2005), fish-bone phosphopeptide with the high affinity to $\mathrm{Ca}$ had been isolated from hoki (Johnius belengerii) skeletons discarded from industrial processing. The present study in vivo was undertaken to evaluate the beneficial effects of fish-bone peptide (FBP) as a Ca fortifier.

\section{Materials and methods \\ Preparation of fish-bone peptides with calcium-binding activity}

FBP with a high affinity to Ca were isolated from hoki boneprotein hydrolysates using a hydroxyapatite affinity column. Hoki bone powder was digested with Thunnus thynnus (bluefin tuna) intestine crude enzyme ( $\mathrm{pH} 9.0 ; 40^{\circ} \mathrm{C}$; enzyme-substrate, 1:100; substrate concentration, $1 \%$ ) for $48 \mathrm{~h}$ according to the method of Kim et al. (2003). After incubation at $100^{\circ} \mathrm{C}$ for $5 \mathrm{~min}$ to inactivate the enzyme, the tuna intestine crude enzyme-digested fish-bone hydrolysates were filtered and demineralised on a Chelex 100 resin (Bio-Rad, Richmond, CA, USA) column. Then the Ca-binding fraction was eluted throughout a hydroxyapatite affinity column $(20 \times 80 \mathrm{~mm}$, 
Macroprep ceramic hydroxyapatite type 1; Bio-Rad) according to a previous method (Jung et al. 2005). After affinity chromatography, the peptide fraction with the highest $\mathrm{Ca}$ affinity was collected and fractionated into three kinds of peptides with different molecular weights (MW $>5 \mathrm{kDa}, 5-1 \mathrm{kDa}$ and $<1 \mathrm{kDa}$ ) using an ultramembrane filter system with MW $5 \cdot 0$ and $1.0 \mathrm{kDa}$ cut-off membranes (SM165; Sartorious, Göttingen, Germany). After chemical analysis, the fractions were lyophilised.

\section{Chemical analysis}

Protein concentration in sample solutions was determined by the method of Lowry et al. (1951) using bovine serum albumin as a standard. After demineralisation of samples with Chelex-100 (Bio-Rad), P was determined by the colorimetric method, using a phosphoprotein phosphate assay kit (Pierce Biotechnology, Inc., Rockfold, IL, USA), and phosvitin (Sigma Chemical Co., St Louis, MO, USA) was used as a standard. Amino acid composition was analysed according to our previous study (Jung et al. 2005). Ca concentration in sample solutions was measured by a flame atomic absorption spectrometer (Simatzu AA-680; Simatzu Co., Tokyo, Japan) fitted with a hollow cathode lamp. Instrumental conditions were wavelength $=422.8 \mathrm{~nm}$, slit $=0.7 \mathrm{~nm}$, acetylene flow $=1.751 / \mathrm{min}$, air flow $=14.01 / \mathrm{min}$, nebuliser $=$ spoiler. Lanthanum solution was added to $0.1 \%$ (w/v) sample solutions.

\section{In vitro calcium-binding assay}

Ca-binding assays were performed according to the method of Jung et al. (2005). Various concentrations of FBP up to $500 \mathrm{mg} / \mathrm{l}$ were mixed with $5 \mathrm{mM}-\mathrm{CaCl}_{2}$ and $20 \mathrm{mM}$-sodium phosphate buffer ( $\mathrm{pH} 7 \cdot 8$ ). The mixture was stirred at $22^{\circ} \mathrm{C}$ for $30 \mathrm{~min}$, and the $\mathrm{pH}$ was maintained at 7.8 in the buffer system. When the $\mathrm{pH}$ changed, it was adjusted with $6 \mathrm{M}$ $\mathrm{HCl}$ or $-\mathrm{NaOH}$ and monitored by a $\mathrm{pH}$ meter (HORIBA D-51 model pH meter; HORIBA Co., Ltd, Kyoto, Japan). After removal of insoluble calcium phosphate salts and filtration using a $0.45 \mu \mathrm{m}$ membrane, the Ca contents of the supernatant fraction were determined by flame atomic absorption spectrometry. The experiments were performed in triplicate; values are expressed as means and standard deviations.

\section{In vivo test of calcium absorption and bone mineral density in} ovariectomised rats

Experimental animals and diets. Sprague-Dawley ovariectomised rats ( $n$ 24; 3 months old) were obtained from Korea Research Institute of Chemical Technology (Daejeon, Korea). The rats were housed in individual shoe-box cages in a temperature- and humidity-controlled room $\left(22 \pm 2{ }^{\circ} \mathrm{C}\right.$ and $60 \pm 5 \%$ relative humidity) with a $12 \mathrm{~h}$ light-dark cycle in accordance with the Guidelines on the Use of Living Animals in Scientific Investigations (Biological Council, 1987). As shown in Table 1, all experimental diets were prepared according to the AIN-76 diet (Anonymous, 1977) with slight modification. The low-Ca diet used in the present study was made from Ca-free AIN-76 salt mix (Ralston Purina International Co., St Louis, MO, USA) with added
Table 1. Composition of the modified AIN-76 diet

\begin{tabular}{lcccc}
\hline & \multicolumn{4}{c}{ Content $(\mathrm{g} / \mathrm{kg})$} \\
\cline { 2 - 5 } & & \multicolumn{3}{c}{ Normal-Ca diet } \\
\cline { 2 - 5 } Ingredients & Low-Ca diet & Control & CPP & FBP \\
\hline Casein & 200.0 & $200 \cdot 0$ & 150.0 & 150.0 \\
CPP & - & - & 50.0 & - \\
FBP & - & - & - & 50.0 \\
DL-Methionine & 3.0 & 3.0 & 3.0 & 3.0 \\
Maize starch & 150.0 & 150.0 & 150.0 & 150.0 \\
Sucrose & 499.8 & 482.5 & 482.5 & 482.5 \\
Cellulose & 50.0 & 50.0 & 50.0 & 50.0 \\
Maize oil & 50.0 & 50.0 & 50.0 & 50.0 \\
Mineral mix & 35.0 & 35.0 & 35.0 & 35.0 \\
Calcium carbonate & 0.175 & 17.5 & 17.5 & 17.5 \\
Vitamin mix & 10.0 & 10.0 & 10.0 & 10.0 \\
Choline bitartrate & 2.0 & 2.0 & 2.0 & 2.0 \\
\hline
\end{tabular}

CPP, casein phosphopeptide; FBP, fish-bone phosphopeptide.

${ }^{*}$ Ca-free AIN-76 mineral mix contains $(\mathrm{g} / \mathrm{kg})$ : potassium phosphate monobasic, 500.00; sodium chloride, 74.00; magnesium sulfate, 36.20; magnesium oxide, 11.90; manganous carbonate, 3.50; ferric citrate, 6.00; zinc carbonate, 1.60; cupric carbonate, 0.30; potassium iodate, 0.01 ; sodium selenate, 0.01 ; chromium potassium sulfate, 0.55 ; finely powdered sucrose, 365.93 .

†AIN-76A vitamin mixture contains $(\mathrm{g} / \mathrm{kg})$ : thiamin $\mathrm{HCl}, 0.60$; riboflavin, 0.60 ; pyridoxine $\mathrm{HCl}, 0.70$; niacin, 3.0; calcium pantothenate, 1.60; folic acid, 0.20; biotin, 0.02 ; vitamin $B_{12}, 1.0$; vitamin A palmitate 0.80 ; vitamin $D_{3} 0.25$; vitamin $E$ acetate 10.00; menadione sodium bisulfite, 0.08 ; finely powdered sucrose, 981.15 For details of diets and procedures, see p. 124.

$\mathrm{CaCO}_{3}(0 \cdot 175 \mathrm{~g} / \mathrm{kg})$ (Shinyo Pure Chemicals Co., Osaka, Japan) as the Ca source. After ovariectomy, rats were fed ad libitum with the low-Ca diet and deionised water for 6 weeks. The rats were then randomly assigned to the control and two experimental groups (eight rats per group). The control group was switched to a normal-Ca diet including $\mathrm{CaCO}_{3}$ $(17.5 \mathrm{~g} / \mathrm{kg})$ for 6 weeks. Rats in the experimental groups were fed on the normal-Ca diet including CPP type II (50 g/ kg) produced by Meiji Seika Co. Ltd (Tokyo, Japan) and FBP II $(50 \mathrm{~g} / \mathrm{kg})$.

\section{Sampling and analytical methods}

Body weight was recorded once per week throughout the 6-week experimental diet. During the $4 \mathrm{~d}$ metabolic balance study at the end of treatment, the amount of food and $\mathrm{Ca}$ intake were monitored by housing each rat individually according to the method of Zafar et al. (2004). Urinary Ca and faecal $\mathrm{Ca}$ excreted were measured by a flame atomic absorption spectrometer. Ca retention (balance) was calculated as: Ca intake - faecal $\mathrm{Ca}$ - urinary $\mathrm{Ca}$. After 6-week feeding periods, the rats were fasted overnight and killed under pentobarbitone anaesthesia. Blood collected from carotid bleeding was centrifuged to separate serum, and serum $\mathrm{Ca}$ was measured by an automatic analyser (ARKRAY model SP4410; Kyoto Daiichi Kagaku Co., Ltd, Kyoto, Japan). Right femurs were excised and connective tissues were cleared. After measuring length and weight, the breaking force of femoral centre was analysed by an INSTRON universal testing instrument (model 1011; Instron Co., Canton, MA, USA). Data were expressed as peak breaking force of femur breaking (kg unit). Broken femurs were dissolved in $3 \mathrm{ml} 70 \% \mathrm{HNO}_{3}$ individually. The diluted femur solution was analysed for total $\mathrm{Ca}$ by flame atomic absorption spectrometry. Bone 
mineral density of the distal region, defined as $5 \%$ of the whole length of the left femur, was determined by dualenergy X-ray absorptiometry (HITACHI BMD-IX; Hitachi Co., Tokyo, Japan).

\section{Statistical analysis}

ANOVA was performed with Duncan's multiple range test using SAS to compare means (SAS Institute, Inc., Cary, NC, USA). The level of significance was $P<0.05$ for all statistical tests.

\section{Results}

Chemical analysis and in vitro assay for calcium-binding activity

FBP with Ca-binding activity were isolated using hydroxyapatite affinity chromatography according to our previous method (Jung et al. 2005). Chemical compositions of FBP I, II and III were analysed as shown in Table 2. The FBP II fraction with the distribution of MW 5.0-1.0 kDa mainly consists of $15.1 \%$ $\mathrm{P}(\mathrm{w} / \mathrm{w})$ and $83.7 \%$ protein (w/w). It consisted of $27.95 \%$ glycine, $12.6 \%$ threonine, $9.7 \%$ alanine, $8.6 \%$ serine, $8.1 \%$ glutamate or glutamine, and $7.3 \%$ hydroxyproline (data not shown). In the assay for Ca-binding activity (Fig. 1), FBP II showed the highest affinity to $\mathrm{Ca}$ as compared with other fractions, but lower than that of CPP. The solubility of Ca was dependent on the concentration of FBP II, and $26.35 \mathrm{mg} \mathrm{Ca} /$ 1 was obtained at a concentration of $200 \mathrm{mg} / \mathrm{l}$ at $\mathrm{pH} 7 \cdot 8$. In the treatment of $200 \mathrm{mg} \mathrm{CPP} / 1,29.64 \mathrm{mg} \mathrm{Ca} / 1$ was analysed in the supernatant fraction after the formation of insoluble salts.

Body weight, food intake, calcium intake, calcium loss and retention

No significant difference in body-weight gain, food intake, and total $\mathrm{Ca}$ intake was found among the three groups (Table 3). Serum Ca level was slightly elevated in both the CPP and FBP II diet groups, but not significantly. The rate of $\mathrm{Ca}$ loss into faeces was significantly lower in the CPP and FBP II diet groups $(P<0.05)$, and higher values of $\mathrm{Ca}$ retention were shown in both dietary groups.

Table 2. Chemical analysis of fish-bone phosphopeptides (FBP)

\begin{tabular}{lcccc}
\hline FBP & $\begin{array}{c}\mathrm{P} \\
(\% ; w / w)\end{array}$ & $\begin{array}{c}\text { Protein } \\
(\% ; w / w)\end{array}$ & $\begin{array}{c}\text { Distribution of MW } \\
(\mathrm{kDa}) \dagger\end{array}$ & $\begin{array}{c}\text { Yield } \\
(\% ; w / w)\end{array}$ \\
\hline Total $^{*}$ & 6.5 & 92.7 & $>29.0$ & 100.0 \\
FBP I & 5.3 & 93.9 & $>5.0$ & 59.0 \\
FBP II & 15.1 & 83.7 & $5.0-1.0$ & 17.6 \\
FBP III & 2.9 & 95.6 & $<1.0$ & 23.4 \\
\hline
\end{tabular}

MW, molecular weight.

*Total FBP before fractionation. FBP I, II, and III with different MW were fractionated by ultramembrane filtration with $5.0 \mathrm{kDa}$ and $1 \mathrm{kDa}$ cut-off membranes.

tThe MW distribution of total hydrolysates was measured by gel permeation chromatography using a Shodex Ohpak SB-803 HQ (Shodex denco; Shoko Co. Ltd; Tokyo, Japan), and compared with those of molecular markers (bovine serum albumin, 66.0 kDa; carbonic anhydrase, $29.0 \mathrm{kDa}$; cytochrome C, $12.3 \mathrm{kDa}$; aprotinin, 6.5 kDa; ACE I, $13.0 \mathrm{kDa}$ ).

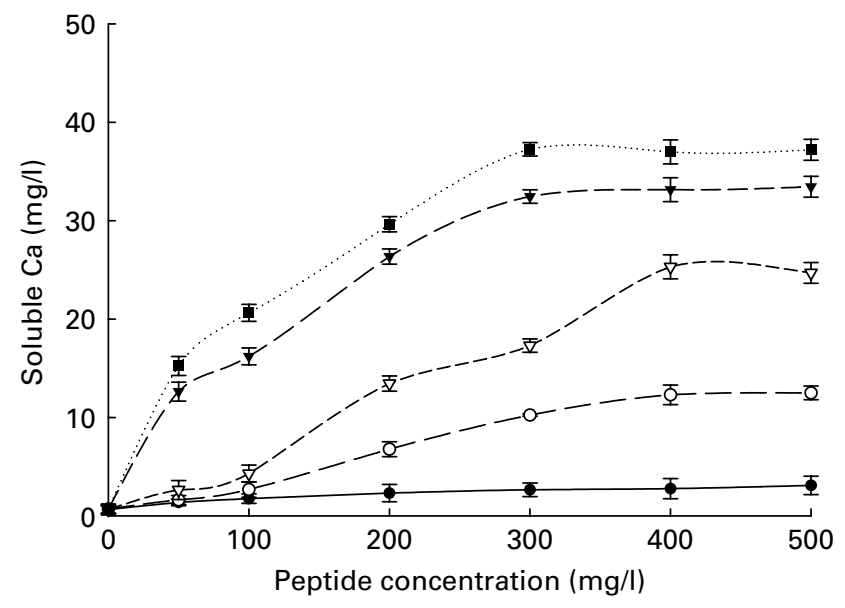

Fig. 1. In vitro Ca-binding activity of fish-bone peptides (FBP). Various concentrations up to $500 \mathrm{mg} \mathrm{FBP} / \mathrm{l}$ were mixed with $5 \mathrm{mM}-\mathrm{CaCl}_{2}$ and $20 \mathrm{~mm}$ sodium phosphate buffer $(\mathrm{pH} 7 \cdot 8)$. The mixture was stirred at $22^{\circ} \mathrm{C}$ for $30 \mathrm{~min}$, and the $\mathrm{pH}$ was maintained at 7.8 in the buffer system. When the $\mathrm{pH}$ changed, it was adjusted with $6 \mathrm{M}-\mathrm{HCl}$ or $-\mathrm{NaOH}$ and monitored by a $\mathrm{pH}$ meter. After removal of insoluble calcium phosphate salts and filtration with a $0.45 \mu \mathrm{m}$ membrane, Ca contents of the supernatant fraction were determined by flame atomic absorption spectrometry. The experiments were performed in triplicate. Values are means, with standard deviations represented by verti-

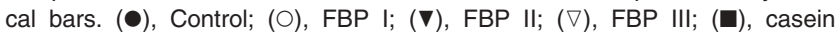
phosphopeptide.

\section{Femur analysis}

The effects of the FBP II diet on the femur are presented in Table 4. A significant increase of the femoral weight was observed in the FBP II compared with the control $(P<0.05)$. An increase in the femoral total $\mathrm{Ca}$ was also found in the FBP II-fed animals. The treatment with FBP II increased the bone mineral density of the distal region $(P<0.05)$ and the breaking force of the proximal region $(P<0.05)$ in the femur.

\section{Discussion}

FBP with high Ca-binding activity were isolated using hydroxyapatite affinity chromatography according to our previous method (Jung et al. 2005), and the Ca-binding peptide FBP II with a high content of $\mathrm{P}(15.1 \%)$ was fractionated in the range of MW 5.0-1.0 kDa. It was composed of high contents of $27.95 \%$ glycine, $12.6 \%$ threonine, $9.7 \%$ alanine, $8.6 \%$ serine, $8.1 \%$ glutamate or glutamine, and $7.3 \%$ hydroxyproline. All essential amino acids except for tryptophan (below $0 \cdot 1 \mathrm{mg}$ tryptophan $/ 100 \mathrm{mg}$ total amino acids) were detected in the FBP II.

As reported by Jiang \& Mine (2000), the solubility of $36.3 \mathrm{mg} \mathrm{Ca} / \mathrm{l}$ was obtained at $200 \mathrm{mg}$ oligophosphopeptide from egg yolk phosvitin/l, with $35 \%$ phosphate retention, and the solubility was higher than that of commercial CPP II. As reported by Hoang et al. (2003), Ca-binding phosphoproteins, such as osteocalcin, can recognise $\mathrm{Ca}$ on the surface of hydroxyapatite. Dohi et al. (1987) isolated two Ca-binding proteins with the $\gamma$-carboxyglutamic acid (gla protein) domain from bullfrog Rana catesbiana using hydroxyapatite affinity chromatography. The present study in vitro elucidated that FBP with the high affinity to Ca was produced from enzymic 
Table 3. Effects of fish-bone peptide (FBP) II intake on body weight, calcium intake and calcium retention in ovariectomised rats

(Mean values and standard deviations)

\begin{tabular}{|c|c|c|c|c|c|c|}
\hline \multirow[b]{2}{*}{ Experimental groups... } & \multicolumn{2}{|c|}{ Control (n 8) } & \multicolumn{2}{|c|}{ CPP $(n 8)$} & \multicolumn{2}{|c|}{ FBP II (n 8) } \\
\hline & Mean & SD & Mean & SD & Mean & SD \\
\hline Body-weight gain $(\mathrm{g} / \mathrm{d})$ & $14 \cdot 4$ & 1.5 & $14 \cdot 2$ & $2 \cdot 5$ & $13 \cdot 9$ & 1.9 \\
\hline Food intake $(\mathrm{g} / \mathrm{d})$ & $12 \cdot 9$ & 0.9 & $13 \cdot 0$ & $1 \cdot 3$ & $12 \cdot 5$ & 1.5 \\
\hline Ca intake (mg/d) & $54 \cdot 8$ & $5 \cdot 9$ & $54 \cdot 2$ & $4 \cdot 8$ & $54 \cdot 4$ & $5 \cdot 5$ \\
\hline Faecal Ca (mg/d) & $53 \cdot 3^{a}$ & $3 \cdot 4$ & $44 \cdot 8^{b}$ & $4 \cdot 2$ & $46 \cdot 5^{a, b}$ & $3 \cdot 6$ \\
\hline Urinary $\mathrm{Ca}(\mathrm{mg} / \mathrm{d})$ & 0.9 & 0.4 & 1.4 & 0.5 & 1.5 & 0.5 \\
\hline Ca retention $(\mathrm{mg} / \mathrm{d})^{*}$ & $0.2^{\mathrm{a}}$ & 0.5 & $8 \cdot 0^{\mathrm{b}}$ & $1 \cdot 2$ & $6 \cdot 4^{\mathrm{b}}$ & $1 \cdot 7$ \\
\hline Serum Ca (mg/l) & $106 \cdot 7$ & $12 \cdot 9$ & $119 \cdot 7$ & $20 \cdot 9$ & $120 \cdot 6$ & $18 \cdot 6$ \\
\hline
\end{tabular}

CPP, casein phosphopeptide.

a,b Mean values within a row with unlike superscript letters were significantly different $(P<0.05)$.

${ }^{*}$ Ca retention (balance) was calculated as: Ca intake - faecal $\mathrm{Ca}$ - urinary Ca (Zafar et al. 2004).

For details of diets and procedures, see p. 124

Table 4. Effects of fish-bone peptide (FBP) II intake on femur in ovariectomised rats (Mean values and standard deviations)

\begin{tabular}{|c|c|c|c|c|c|c|}
\hline \multirow[b]{2}{*}{ Experimental groups... } & \multicolumn{2}{|c|}{ Control $(n 8)$} & \multicolumn{2}{|c|}{$\mathrm{CPP}(n 8)$} & \multicolumn{2}{|c|}{ FBP II $(n 8)$} \\
\hline & Mean & SD & Mean & SD & Mean & SD \\
\hline Femoral total $\mathrm{Ca}(\mathrm{mg})$ & $143^{a}$ & 7 & $153^{b}$ & 9 & $155^{\mathrm{b}}$ & 10 \\
\hline Femur length (mm) & 33.9 & 0.5 & $34 \cdot 8$ & 0.4 & $34 \cdot 3$ & 0.6 \\
\hline Femur wet weight $(\mathrm{g})$ & $1 \cdot 12^{\mathrm{a}}$ & 0.06 & $1 \cdot 32^{b}$ & 0.05 & $1 \cdot 22^{\mathrm{a}, \mathrm{b}}$ & 0.06 \\
\hline Bone mineral density of the distal femur $\left(\mathrm{g} / \mathrm{cm}^{2}\right)$ & $0 \cdot 161^{a}$ & 0.018 & $0.229^{b}$ & 0.029 & $0 \cdot 213^{b}$ & 0.025 \\
\hline Breaking force $(\mathrm{kg})$ & $3.96^{\mathrm{a}}$ & 0.57 & $8.97^{\mathrm{b}}$ & 1.03 & $8.48^{b}$ & 0.97 \\
\hline
\end{tabular}

CPP, casein phosphopeptide.

a,b Mean values within a row with unlike superscript letters were significantly different $(P<0.05)$

For details of diets and procedures, see p. 124.

hydrolysates using the hydroxyapatite affinity column and the MW cut-off ultramembrane filtration, and could increase Ca solubility in the presence of phosphate under the neutral $\mathrm{pH}$.

In vivo effects of FBP II on Ca bioavailability were further studied in the ovariectomised rats. Menopause is a time when oestrogen deficiency leads to accelerated bone resorption and negative bone balance. The present study was undertaken to evaluate the beneficial effects of FBP as a Ca fortifier in osteoporosis induced by ovariectomy and a concurrent low-Ca diet. During the experimental period corresponding to the menopause with osteoporosis disease, the loss of bone mineral (Ca) was decreased by FBP II supplementation in the ovariectomised rats. After the low-Ca diet, the FBP II diet, including both normal levels of $\mathrm{Ca}$ and vitamin $\mathrm{D}$, significantly decreased $\mathrm{Ca}$ loss in faeces and increased $\mathrm{Ca}$ retention as compared with the control. The levels of femoral total $\mathrm{Ca}$, bone mineral density, and breaking strength were also significantly increased by the FBP II diet to a level similar to those of the CPP diet group (no difference; $P>0 \cdot 05$ ). It illustrates that the increased $\mathrm{Ca}$ retention by FBP II intake led to the prevention of mineral loss in the osteoporosis-modelling rats.

As reported by Larsen et al. (2000), the intake of small fish with bones can increase Ca bioavailability, and the small fish may be an important source of $\mathrm{Ca}$, especially in population groups with low intakes of milk and dairy products. In the present study, the results proved the beneficial effects of fishmeal in preventing $\mathrm{Ca}$ deficiency due to increased $\mathrm{Ca}$ bioavailability by FBP intake. Furthermore, it is possible to provide a novel nutraceutical with a high bioavailability for $\mathrm{Ca}$ to oriental people with lactose indigestion and intolerance and Ca-fortified supplements, such as fruit juice or Ca-rich foods, as alternatives to dairy products.

\section{Acknowledgements}

This research was supported by a grant ( $p-2004-01)$ from the Marine Bioprocess Research Center of the Marine Bio 21 Center funded by the Ministry of Maritime Affairs and Fisheries, Republic of Korea.

\section{References}

Anderson JJB \& Garner SC (1996) Calcium and phosphorous nutrition in health and disease. In Calcium and Phosphorous in Health and Disease, pp. 1-5 [JJB Anderson and SC Garner, editors]. New York: CRC Press.

Anonymous (1977) Anonymous Report of the American Institute of Nutrition ad hoc committee on standards for nutritional studies. J Nutr 107, 1340-1348.

Berrocal R, Chanton S, Juillerat MA, Pavillard B, Scherz JC \& Jost R (1989) Tryptic phosphopeptides from whole casein. II. Physiochemical properties related to the solubilization of calcium. J Dairy Res 56, 335-341.

Biological Council (1987) Guidelines on the Use of Living Animals in Scientific Investigations. London: Institute of Biology.

Brouns F \& Vermeer C (2000) Functional food ingredients for reducing the risks of osteoporosis. Trends Food Sci Tech 11, 22-33. 
Dohi Y, Iwami K, Yonemasu K \& Moriyama T (1987) Two proteins with gamma-carboxyglutamic acid in frog bone: isolation and comparative characterization. $B B A$ 915, 378-384.

Hoang QQ, Sicheri F, Howard AJ \& Yang DSC (2003) Bone recognition mechanism of porcine osteocalcin from crystal structure. Nature 425, 977-980.

Jiang B \& Mine Y (2000) Preparation of novel functional oligophosphopeptides from hen egg yolk phosvitin. J Agr Food Chem 48, 990-994.

Jung WK, Park PJ, Byun HG, Moon SH \& Kim SK (2005) Preparation of hoki (Johnius belengerii) bone oligophosphopeptide with a high affinity to calcium by carnivorous intestine crude proteinase. Food Chem 91, 333-340.

Kim SK, Jeon YJ, Byun HG, Kim YT \& Lee CK (1997) Enzymatic recovery of cod frame proteins with crude proteinase from tuna pyloric caeca. Fisher Sci 63, 421-427.

Kim SK, Kim YT, Byun HG, Nam KS, Joo DS \& Shahidi F (2001) Isolation and characterization of antioxidative peptides from gelatin hydrolysate of Alaska pollack skin. J Agri Food Chem 49, 1984-1989.

Kumagai H, Koizumi A, Sato N, Ishikawa Y, Suda A, Sakurai H \& Kumagai H (2004) Effect of phytate-removal and deamidation of soybean proteins on calcium absorption in the in situ rats. Biofactors 22, 21-24.

Larsen T, Thilsted SH, Biswas SK \& Tetens I (2003) The leafy vegetable amaranth (Amaranthus gangeticus) is a potent inhibitor of calcium bioavailability and retention in rice-based diets. Br J Nutr 90, 521-527.

Larsen T, Thilsted SH, Kongsbak K \& Hansen M (2000) Whole small fish as a rich calcium source. Br J Nutr 83, 191-196.
Lee YS, Noguchi T \& Naito H (1980) Phosphopeptides and soluble calcium in the small intestine of rats given a casein diet. $\mathrm{Br} J$ Nutr 43, 457-467.

Lowry OH, Rosebrough AL, Farr AL \& Randall RJ (1951) Protein measurement with the Folin phenol reagent. J Biol Chem 193, $265-275$.

Nagai T \& Suzuki N (2000) Isolation of collagen from fish waste material - skin, bone and fins. Food Chem 68, 277-281.

Nair AL \& Gopakumar K (1982) Soluble protein isolate from low cost fish and fish wastes. Fishery Technol 19, 101-103.

Rodriguez-Estrada MT, Chung S \& Chinachoti P (1994) Solids extraction of cod frame and effects on ultrafiltration of the aqueous exract. J Food Sci 59, 799-803.

Shahidi F \& Janak Kamil YVA (2001) Enzymes from fish and aquatic invertebrates and their application in the food industry. Trends Food Sci Tech 12, 435-464.

Tsuchita H, Sekiguchi I, Kuwata T, Igarashi T \& Ezawa I (1993) The effect of casein phosphopeptides on calcium utilization in young ovariectomized rats. Z Ernährungswiss 32, 121-130.

Yuan YV \& Kitts DD (1991) Conformation of calcium absorption and femoral utilization in spontaneously hypertensive rats fed casein phosphopeptide supplemented diets. Nutr Res 11, $1257-1272$.

Yuan YV \& Kitts DD (1994) Calcium absorption and bone utilization in spontaneously hypertensive rats fed on native and heat-damaged casein and soyabean protein. Br J Nutr 71, 583-603.

Zafar TA, Weaver CM, Zhao Y, Martin BR \& Wastney ME (2004) Nondigestible oligosaccharides increase calcium absorption and suppress bone resorption in ovariectomized rats. J Nutr 134, $399-402$. 